Gökdemir, M. ve Yakut, A. D. (2021). Özgül öğrenme güçlüğü olan öğrencilerin okuma becerilerinin incelenmesi. Ana Dili Eğitimi Dergisi, 9(2), 330-342.

Ana Dili Eğitimi Dergisi
Journal of Mother Tongue Education
www.anadiliegitimi.com
Geliş/Received: 07.10.2020 Kabul/Accepted: 27.03 .2021
Araştırma Makalesi / Research Paper

\title{
Özgül Öğrenme Güçlüğü Olan Öğrencilerin Okuma Becerilerinin İncelenmesi*
}

\author{
Mert GÖKDEMiR ${ }^{* *}$ \\ Ayşe Dilşad YAKUT ${ }^{* * *}$
}

Öz

Araştırmanın genel amacı, özgül öğrenme güçlüğü olan öğrencilerin doğru okuma, okuduğunu anlama ve okuma hızı becerilerini inceleyerek öğrencilerin sınıf ve yaş seviyesindeki performanslarını belirlemektir. Araştırma Konya ilinde özel eğitim ve rehabilitasyon merkezlerinde öğrenim gören özgül öğrenme güçlüğü olan 79 üçüncü sınıf öğrencisi ile yürütülmüştür. Öğrencilerin doğru okuma, okuduğunu anlama ve okuma hızı becerilerini değerlendirebilmek amacıyla kullanılan "Sesli Okuma Becerisi ve Okuduğunu Anlama Testi II" kullanıımıştır. Öğrencilerin \%98.73'inin ( $n=78)$ doğru okuma, \%100'ünün $(n=79)$ okuduğunu anlama ve \%100'ünün ( $n=79$ ) okuma hızı becerilerinde kronolojik yaş ve sınıf seviyesinin altında performans gösterdikleri ortaya çıkmıştır. Doğru okuma, okuduğunu anlama ve okuma hızı becerilerinin birbirlerini etkilediği tespit edilmiştir. Elde edilen bulgular ilgili alanyazın ışığında tartışılmıştır.

Anahtar Kelimeler: Doğru okuma, okuduğunu anlama, okuma hızı, özgül öğrenme güçlüğü

\begin{abstract}
Examining Reading Skills of Students with Specific Learning Disabilities
Abstract

The purpose of this study is to determine the performance of students with specific learning disabilities at specific grade and age level by examining their reading accuracy, reading comprehension, and reading rate. This study was conducted with 79 third grade students with specific learning disabilities who were receiving their education in special education and rehabilitation centers in Konya province. The Oral Reading Skill and Reading Comprehension Test, used to evaluate the reading accuracy, reading comprehension, and reading rate of students, was administered in this study. Findings of the study showed that students with specific learning disabilities performed below their chronological ages and grade levels in reading accuracy (98.73\%), reading comprehension (100\%), and reading rate (100\%). Reading accuracy, reading comprehension, and reading rate were found to influence each other. The findings were discussed in the light of the relevant literature.
\end{abstract}

Keywords: Reading accuracy, reading comprehension, reading rate, specific learning disabilities

\section{Giriş}

Özgül öğrenme güçlüğü olan birey; "dili yazılı ya da sözlü anlamak ve kullanabilmek için gerekli olan bilgi alma süreçlerinin birinde veya birkaçında ortaya çıkan ve dinleme, konuşma, okuma, yazma, heceleme, dikkat yoğunlaştırma ya da matematiksel işlemleri yapma güçlüğü nedeniyle özel

\footnotetext{
* Bu makale, Mert Gökdemir’in “Özgül Öğrenme Güçlüğü Olan Öğrencilerin Doğru Okuma, Okuduğunu Anlama ve Okuma Hızlarının İncelenmesi” adlı yüksek lisans tezinden üretilmiş olup çalışmanın erken bir örneği FSMVUEAK 2020 Eğitim Araştırmaları Kongresi'nde sözlü bildiri olarak sunulmuştur.

** Öğretmen, Milli Eğitim Bakanlığı, Konya, mertgokdemir@hotmail.com, ORCID: orcid.org/0000-0003-47176583

${ }^{* * *}$ Dr. Öğr. Üyesi, İbn Haldun Üniversitesi, Eğitim Bilimleri Fakültesi, Rehberlik ve Psikolojik Danışmanlık Bölümü, İstanbul, ayse.yakut@ihu.edu.tr, ORCID: orcid.org/0000-0001-8277-6213
} 
eğitim ve destek eğitim hizmetine ihtiyacı olan birey" şeklinde tanımlanmıştır (Milli Eğitim Bakanlığı Özel Eğitim Hizmetleri Yönetmeliği, 2006). Bu güçlüğe sahip olan öğrenciler, okuma, yazma veya matematik alanlarından herhangi birinde zorluklar yaşarken yine aynı alanların birinde üstün başarıya sahip olabilirler (Harwell ve Jackson, 2008). Ülkemizde özgül öğrenme güçlüğü olan öğrenciler genellikle tam zamanlı kaynaştırma öğrencisi olarak eğitim görmektedir. Sınıflarında kaynaştırma öğrencisi olan öğretmenlerin bu alanda yeterli eğitime sahip olmaması öğrencilerin eğitsel performansını değerlendirme ve bireyselleştirilmiş eğitim programı oluşturma sürecinde problemlere neden olmaktadır (Vural ve Yıkmış, 2008). Örneğin Kuruyer ve Çakıroğlu (2017) sınıf öğretmenlerinin kaynaştırma öğrencisi olarak eğitim gören özgül öğrenme güçlüğü olan öğrencilerin eğitsel değerlendirme ve müdahale süreçleriyle ilgili görüş ve uygulamalarını incelemiş, yarı yapılandırılmış görüşme ve yapılandırılmamış gözlem tekniği ile yapılan nitel araştırmadan elde edilen bulgular, sınıf öğretmenlerinin eğitsel değerlendirme ve müdahale programı oluşturma konusunda eksikliklerinin olduğunu ve uygulama aşamasında zorluklar yaşadıklarını göstermektedir. Eğitsel değerlendirme sürecinde öğretmenlerin özel öğrenme güçlüğü ile ilgili kavramsal yanılgılarının olduğu, uygulama sürecinde ise özgül öğrenme güçlüğü olan öğrencilere yönelik öğretim planı hazırlamadıkları araştırma bulguları arasındadır. Yapılan bir diğer araştırmada ise Saraç ve Çolak (2012) ilköğretim sınıf öğretmenlerinin kaynaştırma uygulamaları sürecinde yaşadıkları sorunları incelemiştir. Bulgular, öğretmenlerin çoğunun kaynaştırma uygulamalarına ilişkin eğitim almadıklarını ve öğretimsel düzenleme yapmadıklarını, bazı öğretmenlerin bireysel eğitim planı hazırlamadıklarını, bazı öğretmenlerin ise bireysel eğitim planını uygulayamadıklarını göstermiştir. Alanyazın, özgül öğrenme güçlüğü olan kaynaştırma öğrencilerinin eğitimi konusunda öğretmenlerin akademik becerileri değerlendirilme, eğitsel değerlendirme ve gerekli eğitim programı oluşturma konusunda yeterli bilgi ve donanıma sahip olmadığı göstermektedir.

Ülkemizde özgül öğrenme güçlüğü tanısı almış öğrenci sayısı 2007-2008 eğitim öğretim yılında 5500 öğrenci ve 2013-2014 eğitim öğretim yılında ise 7429 öğrenci olup özgül öğrenme güçlüğü oranı tüm özel eğitim öğrencilerinin \%3'ünü oluşturmaktadır (MEB, 2014; Akt. Melekoğlu, 2018). Ülkemizde özgül öğrenme güçlüğü olan öğrencilerin sayısı artış gösterse de bu veriler diğer ülkelere kıyasla düşüktür. Örneğin, Amerika Birleşik Devletleri'nde özgül öğrenme güçlüğü olan öğrenciler, özel eğitim hizmetlerinden faydalanan öğrencilerin \%39,2'sini meydana getirmektedir (The United States Department of Education, 2016). Birçok etmen özgül öğrenme güçlüğü olan öğrencilerin tanılama sürecini etkilese de, bu düşük oran tanılama ile ilgili yetersizliklere işaret etmektedir (Melekoğlu, 2018).

Özgül öğrenme güçlüğüne sahip öğrenciler ortalama veya ortalamanın üzerinde zekâya sahip olup okuma, yazma veya matematik alanlarının herhangi birinde düşük başarı sergilerken yine aynı alanların birinde üstün başarıya sahip olabilirler (Harwell ve Jackson, 2008). Özgül öğrenme güçlüğü olan öğrenciler en fazla okuma becerilerinde problemler yaşamaktadır (American Psychological Association [APA], 2013). Ülkemizde ise özgül öğrenme güçlüğü olan öğrencilerin \% 90 'ında okuma problemi olduğu tahmin edilmektedir (Çakıroğlu, 2018). Benzer bir şekilde Amerika Birleşik Devletleri'nde yapılan bir araştırmaya göre özgül öğrenme güçlüğü içinde yaklaşık \%80 ile en fazla görülen problemin okuma alanında olduğu saptanmıştır (Harwell ve Jackson, 2008). Özetle okuma güçlüğü olan öğrenciler doğru okuma, okuduğunu anlama ve okuma hızında yaşıtlarının altında performans sergilediği görülmektedir.

Doğru okuma öğrencinin metinde doğru okuduğu kelime oranı şeklinde tanımlanmaktadır (Keskin ve Akyol, 2014). Doğru okuma, metinleri seslendirirken ses ve harflerin uyumlu bir şekilde kullanılmasını ve kelimelerin tanınmasını gerektirmektedir (Katzir ve diğerleri, 2006). Özgül öğrenme güçlüğü olan öğrencilerin doğru okuma alanında problem sergilediklerini gösteren araştırmalar mevcuttur. Örneğin, Jenkins, Furhs, Broek, Espin ve Deno (2003) dördüncü sınıfta öğrenim gören, okuma yetersizliğine sahip olan 24 öğrenci ve okuma yetersizliğine sahip olmayan 85 öğrenci olmak üzere toplam 109 öğrencinin okuma doğruluklarını değerlendirmişlerdir. Araştırma bulguları okuma yetersizliği olmayan öğrencilerin, okuma yetersizliği olan öğrencilere kıyasla dakikada üç kat daha fazla kelimeyi doğru okuduklarını göstermiştir. Araştırmacılar özgül öğrenme güçlüğü olan öğrencilerin okuma doğruluğunun düşük çıkmasını kelime bilgilerinin akranlarına göre düşük seviyede 
olmasına bağlamışlardır. Bir diğer araştırmada ise Seçkin Yılmaz ve Baydık (2017) okuma hızı yetersiz olan $(n=26)$ ve okuma hızı yetersiz olmayan $(n=26)$ üçüncü sınıf öğrencilerinin okuma becerilerini karşılaştırmıştır. Okuma hızı yetersiz olan öğrencilerin okuma hızı yetersiz olmayan öğrencilere göre doğru okuma becerilerinde daha düşük olduğu bulunmuştur.

Rasinski (2004) okuma hızını öğrencinin dakikada okumuş olduğu doğru kelime sayısı olarak tanımlamaktadır. Öğrenciler okumayı anlamı bozmadan, noktalama işaretlerine uyarak ve akranları seviyesinde bir hız ile tamamlamalıdır (Varol, 2017). Akyol (2012) ise öğrencilerin sınıf seviyelerine göre okuma hızlarını; birinci ve ikinci sınıfta öğrenim gören öğrencilerde 25-100, üçüncü ve dördüncü sınıfta öğrenim gören öğrencilerde 100-200, beşinci ve altıncı sınıfta öğrenim gören öğrencilerde 200300 ve yedinci ve sekizinci sınıfta öğrenim gören öğrencilerde 300-350 kelime olarak belirtmiştir. Sarıpınar ve Erden (2010) ise ilköğretime devam eden ve okuma güçlüğü tanısı almış öğrencilerin okuma hızlarını, okuduğunu anlama ve okuma hatalarını incelemiştir. Araştırmaya 64 okuma güçlüğü olan ve 64 okuma güçlüğü olmayan öğrenci katılmıştır. Araştırmanın bulgularına göre öğrenciler dakikada ortalama 43.40 kelime okumuşlardır. Okuma güçlüğü olan öğrenciler okuma güçlüğü olmayan öğrencilere göre okuma hızı, okuduğunu anlama ve okuma hatalarında daha düşük performanslar sergilediği sonucuna ulaşılmıştır. Araştırmalardan anlaşılacağı gibi okuma hızı becerilerinde özgül öğrenme güçlüğü olan öğrenciler özgül öğrenme güçlüğü olmayan öğrencilere daha düşük seviyede performans göstermiştir.

Özgül öğrenme güçlüğü olan öğrencilerin problem yaşadığı alanlardan biri de okuduğunu anlamadır (Pierangelo ve Giuliani, 2006). Okuduğunu anlama "öğrencilerin okuma esnasında okuyucunun ön bilgilerini, deneyimlerini ve muhakeme becerilerini kullanarak metinde sunulan görseller ve diğer kavramlardan da yararlanarak anlam çıkarması" olarak tanımlanmıştır (Akyol, 2018:3). Okumanın gerçek anlamıyla olması, anlamayı gerektirir. Eğer okumanın sonucu okuduğunu anlama ile sonuçlanmıyorsa, okuma sadece robotik bir beceri olarak kalmaktadır. Öğrencinin okuduğunu anlaması için, metinde bulunan kelimeleri tanıması ve bu kelimelerin anlamını kendi zihninde canlandırması gerekmektedir (Vellutino, Fletcher, Snowling ve Scanlon, 2004). Carr ve Thompson (1996), özgül öğrenme güçlüğü olan ve olmayan öğrencilerin okuduğunu anlama becerilerini karşılaştırmıştır. Araştırmaya sekizinci sınıfa devam eden özgül öğrenme güçlüğü olan 16 öğrenci, sekizinci sınıfa devam eden özgül öğrenme güçlüğü olmayan 16 öğrenci ve özgül öğrenme güçlüğü olan öğrencilerle benzer okuma seviyesine sahip olan ve beşinci sınıfa devam eden 16 öğrenci katılmıştır. Araştırmada bütün öğrencilere metinler okutulmuş ve metinlerle alakalı çoktan seçmeli sorular sorulmuştur. Özgül öğrenme güçlüğü olan öğrenciler okuduğunu anlama sorularında akranlarına göre düşük performans sergilediği ve beşinci sınıfa devam eden öğrencilerle yakın seviyede olduğu sonucuna ulaşılmıştır. Diğer bir araştırmada Güldenoğlu, Kargın ve Milller (2012) okuma yetersizliği olan $(n=23)$ ve okuma yetersizliği olmayan $(n=26)$ ikinci sınıfa devam eden öğrencilerin okuduğunu anlama ve kelime işlemleme becerilerini karşılaştırmıştır. Araştırmada veriler üç işlem ve bilgi formu ile toplanmıştır. Araştırmada okuma yetersizliği olmayan öğrencilerin, okuma yetersizliği olan öğrencilere göre daha iyi okuduğunu anlama ve kelime işlemleme becerisine sahip olduğu, okuduğunu anlama ve kelime okuma becerisinin birbirlerini yordadığı bulunmuştur. Diğer bir araştırmada ise Dündar ve Akyol (2014) okuma yetersizliği olan ikinci sınıf öğrencisinin okuma ve okuduğunu anlama problemlerinin giderilmesine yönelik deneysel bir çalışma yapmıştır. Yanlış analiz envanteri ile öğrencinin atlama, ekleme, yanlış okuma ve ters okuma hataları yaptığını tespit edilmiştir. Öğrenciye müdahale programı uygulanmadan önce yapılan ön testte öğrencinin okuma becerilerinin endişe düzeyinde olduğu belirlenmiştir. Öğrenciye 11 haftalık bir müdahale programı uygulanmış ve müdahale programından sonra öğrencinin okuma hatalarında azalma ve okuduğunu anlama becerilerinde gelişme gözlemlenmiştir. Öğrenciye müdahale programından sonra yapılan son testte okuma becerilerinin öğretim düzeyinde olduğu bulgusuna ulaşılmıştır. Kordan ve Akyol (2018) okuma yetersizliği olan öğrencilerin koro, tekrarlı okuma ve yardımlı okuma yöntemlerinin okuma ve okuduğunu anlama becerilerine etkisini incelemiştir. Tek denekli araştırma yöntemi ile tasarlanan araştırmaya okuma yetersizliği olan 6 öğrenci katılmıştır. Araştırmada öğrencilerin okuma ve okuduğunu anlama becerilerinde endişe düzeyinde olduğu ve yapılan müdahale sonucunda okuma ve okuduğunu anlama becerilerinin geliştiği sonucuna ulaşılmıştır. Araştırmalardan da anlaşıldığı gibi 
özgül öğrenme güçlüğü olan öğrenciler okuduğunu anlama becerilerinde akranlarından daha düşük seviyede performans göstermektedir.

\section{Araştırmanın Önemi}

Okuma becerisi, eğitim hayatının ilk yıllarında kazanılması gereken ana beceridir. Eğitimde "Matthew Etkisi" teorisi okuma yazma eğitimine başarıyla başlayan öğrencilerin daha sonraki yıllarda başarılı olmaya devam edeceği, okumayı üçüncü veya dördüncü sınıftan önce öğrenmeyen öğrencilerin ise daha da başarısız olacağıyla ilgili yaklaşımdır (Stanovich, 2009). Bu durumun önlenebilmesi için öğrencilerin erken tanılanması ve doğru müdahalelerin zamanında yapılması gerekmektedir. Aksi takdirde başarılı okuyucular ile başarısız okuyucular arasındaki seviye farkı başarısız olan öğrencilerin okumaya karşı daha az istekli olması nedeniyle kapatılamayacak bir duruma gelebilir, okuma sorunu yaşayan öğrencinin gelecek yaşamını olumsuz olarak etkiler (Stanovich, 2009).

Alanyazında özgül öğrenme güçlüğü olan öğrencilerin doğru okuma, okuduğunu anlama ve okuma hızının bir arada incelendiği araştırmalar sınırıdır (Seçkin, Yılmaz, Baydık, 2017; Melekoğlu, Erden ve Çakıroğlu, 2019; Çelik, Erden, Özmen ve Hesapçıŏlu, 2018). Öğrenciler için müdahale planı oluşturulurken öğrencilerin doğru okuma, okuduğunu anlama ve okuma hızı seviyelerinin öğretmenler tarafından değerlendirilmesi ve öğrencilerin performanslarının takip edilmesi açısından kolaylık sağlayacaktır. Ayrıca öğrencinin ve müdahalenin etkililiğinin değerlendirilmesine yardımcı olacaktır. Sonuç olarak özgül öğrenme güçlügü̈ olan öğrencilere uygulanacak müdahalenin ilk aşaması seviye tespitidir. Bu araştırmada özgül öğrenme güçlüğü tanısı almış öğrencilerin doğru okuma, okuduğunu anlama ve okuma hızı becerileri incelenecek olup olası müdahale programları için öğretmenlere yol gösterecektir.

\section{Araştırmanın Amacı}

Bu araştırmanın amacı, özgül öğrenme güçlüğü olan öğrencilerin doğru okuma, okuduğunu anlama ve okuma hızlarının incelenerek bu öğrencilerin sınıf ve yaş seviyesindeki performanslarının belirlenmesidir. Bu amaç doğrultusunda aşağıda yer alan sorulara yanıt aranacaktır: (1) Özgül öğrenme güçlüğü olan öğrenciler doğru okuma becerisinde sınıf seviyesinde performans gösteriyorlar mı? (2) Özgül öğrenme güçlüğü olan öğrenciler okuma hızında sınıf seviyesinde performans gösteriyorlar mı? (3) Özgül öğrenme güçlüğü olan öğrenciler okuduğunu anlama becerisinde sınıf seviyesinde performans gösteriyorlar mı?

\section{Araştırmanın Modeli}

\section{Yöntem}

Bu araştırma, özgül öğrenme güçlüğü olan öğrencilerin doğru okuma okuduğunu anlama ve okuma hızı becerilerinin sınıf ve yaş seviyelerine göre tespit edildiği tarama modelinde betimsel bir çalışmadır. Tarama modeli geçmişte olan ya da halen var olan bir olayın olduğu gibi betimlemeyi amaçlayan bir araştırma modeldir (Gay, Mills ve Airasian, 2006). Tarama modelinin bir avantajı, çok sayıda bireyden oluşan evrenden genel bir yargıya varmamızı sağlamasıdır (Büyüköztürk, Kılıç Çakmak, Akgün, Karadeniz, \& Demirci, 2008). Özgül öğrenme güçlüğü tanısı almış öğrencilere ulaşma açısından tarama modelinin bu araştırma için elverişli olduğu düşünülmektedir.

\section{Örneklem / Araştırma grubu}

Araştırma grubu, "amaçlı örnekleme" yöntemlerinden "ölçüt örnekleme" yoluyla belirlenmiştir. Amaçlı örneklem, örneklemin evreni temsil edeceği seçilme şeklini belirtmektir. Araştırmaya katılan grubun özellikleri belirlenerek seçilmesini, ölçüt örnekleme şeklinde ifade edilmektedir (Gay ve diğerleri, 2006). Bu araştırmada a) öğrencilerin birlikte çalıştıkları özel eğitim öğretmenleri tarafından çalışma için önkoşul olan kelime düzeyinde okuma becerisine sahip olma, b) üçüncü sınıf öğrencisi olma, c) özgül öğrenme güçlüğü tanısı almış olma ve d) en az 15 dakika dikkat süresine sahip olma araştırmaya alınma kriterleri olarak belirlenmiştir. Özgül öğrenme güçlüğü dışında bir tanıya sahip olma ise araştırmadan dışlanma kriteri olarak belirlenmiştir. 
Konya ilinde bulunan 30 özel eğitim ve rehabilitasyon merkezi ile görüşülerek kuruma devam eden ve üçüncü sınıfta öğrenim gören 305 özgül öğrenme güçlüğü öğrencisi tespit edilmiştir. Gerekli izinler alındıktan sonra araştırmaya dahil olmak isteyen 11 özel eğitim ve rehabilitasyon merkezinde öğrenim gören 68 erkek (\%68) ve 32 kız (\%32) olmak üzere toplam 100 üçüncü sınıf öğrencisinden veri toplanmıştır.

\section{Veri Toplama Araçları}

Bu araştırmada veri toplama aracı olarak Sesli Okuma Becerisi ve Okuduğunu Anlama Testi-II uygulanmıştır. SOBAT-II,7-11 yaşları arasında olan çocukların okuma hızı, akıcı okuma, doğru okuma becerisi ve okuduğunu anlama becerisini değerlendirilebilmek amacıyla Melekoğlu, Erden ve Çakıroğlu (2019) tarafından geliştirilmiştir. SOBAT-II, A ve B formu olarak iki adet benzer formdan meydana gelmektedir. Her bir form toplam 13 metinden oluşmaktadır. En kısa metinde 16 kelime, en uzun metinde ise 338 kelime vardır. Testteki her bir formda yer alan metinlerin zorluk seviyesi gittikçe artmaktadır. Yazı tipi ve büyüklükleri farklı olan metinler, süreölçer kullanılarak çocuğa sesli olarak okutulmakta, bu sırada çocukların hatalı okudukları kelimeler kayıt edilmektedir. Formda bulunan bütün metinlerin sonunda çocuklara metinle alakalı çoktan seçmeli beş soru yöneltilmektedir. Öğrenciler, metinleri okurken üç metinde üst üste 10 ve üzeri hata yaptıklarında uygulama sonlandırılmaktadır (Melekoğlu ve diğerleri, 2019). Araştırmacı veri toplama aşamasından önce SOBAT-II uygulayıcı kullanım sertifika eğitimine katılarak uygulama ile ilgili gerekli olan bilgi ve becerileri kazanmıştır.

\section{İşlem / Verilerin Toplanması}

Veri toplamada şu aşamalar izlenmiştir: (1) Araştırma için gerekli olan Etik Kurul izni alındıktan sonra Konya ilinde yer alan 30 özel eğitim ve rehabilitasyon merkezi ile görüşülmüştür. (2) Araştırmaya 11 özel eğitim ve rehabilitasyon merkezi dahil olmak için onam vermiştir. (3) Araştırmaya dahil olmak isteyen 11 özel eğitim ve rehabilitasyon merkezi idarecileri ile iletişime geçilmiş, ailelerden ve öğrencilerden onam formu alınmıştır. (4) Ailelerden ve öğrencilerden onam formu alındıktan sonra veri toplamaya başlanmıştır. Öğrenci veya veli herhangi bir durumda araştırmaya devam etmek istemediklerinde ise uygulama sonlandırılmıştır.

Özel eğitim ve rehabilitasyon merkezlerinde öğrenim gören 100 üçüncü sınıf öğrencisi tespit edildikten sonra araştırma için önkoşul olan kelime düzeyinde okuma becerisi edinememiş 18 erkek ve 3 kız olmak üzere toplamda 21 öğrenci (\%21) araştırma dışı bırakıımıştır. Araştırma 50 erkek (\%63) ve 29 kız (\%37) olmak üzere toplamda 79 özgül öğrenme güçlüğü olan öğrenci ile yapılmıştır. Betimsel olarak yapılan araştırmalarda evrenin en az \%10'unun örneklem olarak alınması gerekmektedir (Gay, 1987; Aktaran: Arlı ve Nazik, 2010). Araştırma örnekleminin evrene oranı \%25.90 (79/305*100) şeklinde hesaplanmıştır. Bu durumda örneklemin evreni temsil ettiği görülmektedir.

Veri toplama sürecinde, özel eğitim ve rehabilitasyon merkezlerindeki sınıflarda masa, sandalye ve kitaplık dışında dikkat dağıtacak nesnelerin bulunmamasına dikkat edilmiştir. Sınıfın ses, ışık ve temizlik yönlerinden uygun olmasına önem verilmiştir. Sınıf içinde bulunan masaya araştırmacı ve öğrenci, karşıııkı oturacak şekilde bir plan yapılmıştır. Uygun ortam sağlandıktan sonra SOBAT-ıI başlangıç yönergesi ile araştırmaya başlanmıştır. Öğrenci metini okumaya başlaması ile süreölçer başlatılmıştır ve yapılan hatalar araştırmacı önünde bulunan forma not alınmıştır. Metini okuyan öğrenciye daha sonra metinle ilgili beş soru araştırmacı tarafından okunmuştur. Sorulan sorulara öğrencinin verdiği cevaplar araştırmacının önündeki forma kaydedilmiştir. Her metin için bu süreç devam etmiştir. Öğrencinin üç metin üst üste 10 ve üstü hata yaptığı durumda öğrenciye araştırmaya katıldığı için teşekkür ederek SOBAT uygulamasına son verilmiştir.

\section{Verilerin Analizi}

Araştırmada kullanılan öğrenci kitapçığına, her bir öğrenci için numara verilmiştir. Excel programında doğru okuma, okuduğunu anlama ve okuma hızı tablosu oluşturulup, verilen numaraya göre öğrencilerin ilgili alanlardaki verileri tabloya yazılmıştır. SOBAT-II testi uygulayıcı kitapçığında yer alan doğru okuma, okuma hızı ve okuduğunu anlama becerileri tablolarına göre öğrencilerin standart 
puanları ve yüzdelikleri belirlenmiştir. Ayrıca, öğrencilerin doğru okuma, okuma hızı ve okuduğunu anlama performansları yaş ve sınıf seviyelerine göre hesaplanmıştır.

\section{Geçerlik ve Güvenirlik}

SOBAT-II A formunun Cronbach Alfa güvenirlik verileri okuma hızı için 0.97, doğru okuma için 0.93 ve okuduğunu anlama için 0,60 olarak, SOBAT-II B formunda ise okuma hızı 0.97 , doğru okuma 0.93 ve okuduğunu anlama 0,73 olarak belirlenmiştir (Melekoğlu vd., 2019). SOBAT-II, paralel form güvenilirlik verileri ise okuma hızı 0.92 , doğru okuma 0.87 , okuduğunu anlama 0.82 ve toplam puan 0.91 şeklinde bulunmuştur (Melekoğlu vd., 2019). SOBAT-II B formunun güvenirlilik verileri daha yüksek olduğu için araştırmada bu formu kullanılmıştır.

\section{Araştırma ve Yayın Etiği}

$\mathrm{Bu}$ çalışmada "Yükseköğretim Kurumları Bilimsel Araştırma ve Yayın Etiği Yönergesi" kapsamında uyulması belirtilen tüm kurallara uyulmuştur. Yönergenin ikinci bölümü olan "Bilimsel Araştırma ve Yayın Etiğine Aykırı Eylemler" başlığı altında belirtilen eylemlerden hiçbiri gerçekleştirilmemiştir.

\section{Etik Kurul Izni}

Kurul adı = Biruni Üniversitesi Girişimsel Olmayan Etik Kurulu

Karar tarihi $=07.02 .2020$

Belge sayı numarası $=2020 / 37-18$

\section{Bulgular}

Özgül öğrenme güçlüğü olan öğrencilerin doğru okuma, okuduğunu anlama ve okuma hızı becerileri SOBAT-II testi uygulanarak incelenmiş, elde edilen bulgular tablolar halinde sunulmuş ve açıklanmıştır.

Tablo 1.

Doğru Okuma, Okuma Hızı ve Okuduğunu Anlama

\begin{tabular}{lcccc}
\hline & Minimum & Maksimum & Ortalama Puan & Standart Puan Ortalaması \\
Doğru Okuma & 0 & 32 & 4.75 & 2.03 \\
Okuma Hızı & 0 & 24 & 4.07 & 1.65 \\
Okuduğunu Anlama & 1 & 38 & 17.8 & 1.50 \\
\hline
\end{tabular}

Tablo 1'de öğrencilerin doğru okuma, okuma hızı ve okuduğunu anlama becerilerinde aldıkları en düşük, en yüksek, ortalama ve standart puanlarının ortalamaları verilmiştir. SOBAT-II testi uygulamasında doğru okuma puanında en düşük 0 ve en yüksek ise 32 olduğu bulunmuştur. En düşük doğru okuma puanı 7 yaş veya 2. sınıf altı ve en yüksek doğru okuma puanı ise 8 yaş 6 ay veya 3 . sınıfa denk gelmektedir. Araştırmada doğru okuma puanı ortalaması 4.75 ve standart puan ortalaması ise 2.03 olarak bulunmuştur. Okuma hızı puanı en düşük 0 ve okuma hızı puanı ise en yüksek 24 olduğu bulunmuştur. En düşük okuma hızı puanı 7 yaş veya 2. sınıf altı ve en yüksek okuma hızı puanı ise 7 yaş 6 ay veya 2.5. sınıfa denk gelmektedir. Okuma hızı puanında ortalama 4.07 ve standart puanda ise ortalama 1.65 olarak bulunmuştur. En düşük okuduğunu anlama puanı 1 ve en yüksek okuduğunu anlama puanı ise 38 olduğu bulunmuştur. Okuduğunu anlama puanı en düşük 7 yaş veya 2. sınıf ve en yüksek okuduğunu anlama puanı ise 7 yaş 6 ay veya 2. sınıfa denk gelmektedir. Ortalama okuduğunu anlama puanı 17.8 ve ortalama standart puan ise 1.50 olarak bulunmuştur.

Tablo 2.

Doğru Okuma Becerisi

\begin{tabular}{ccc}
\hline$N$ & Sinıf Seviyesi & $\%$ \\
\hline 75 & $<2$ & 94.94
\end{tabular}


Bu araştırmanın ilk alt amacı olan öğrencilerin doğru okuma becerileri incelenmiştir. Tablo 2'ye göre araştırmaya dâhil edilen özgül öğrenme güçlüğü tanılı 3. sınıf öğrencilerinin \%98.73'ünün ( = 78) doğru okuma becerilerinin sınıf seviyesi altında olduğu bulunmuştur. Öğrencilerin \%94.94'ünün $(n=75)$ doğru okuma becerileri 2. sınıf seviyesinin altında, \%3.79'unun $(n=3)$ ise 2 . sınıf seviyesinde performans göstermiştir. Sadece bir öğrencinin (\%1.27) 3. sınıf seviyesinde doğru okuma becerisine sahip olduğu tespit edilmiştir.

Tablo 3.

Doğru Okuma Becerisi

\begin{tabular}{ccc}
\hline$N$ & Yaş Seviyesi & $\%$ \\
\hline 77 & $<7$ & 97.46 \\
1 & 7 & 1.27 \\
1 & 8.6 & 1.27 \\
\hline
\end{tabular}

$N=79$.

Tablo 3'e göre araştırmaya dâhil edilen özgül öğrenme güçlüğü tanılı 3. sınıf öğrencilerinden \%98.73'ünün ( $n=78$ ) doğru okuma becerisinde kronolojik yaşlarının altında olduğu bulunmuştur. Öğrencilerin \%97.46'sinin ( $n=77$ ) doğru okuma becerileri 7 yaş altında, bir öğrenci (\%1.27) 7 yaş seviyesinde performans göstermiştir. Sadece bir öğrencinin (\%1.27) 8.6 yaş seviyesinde doğru okuma becerisine sahip olduğu tespit edilmiştir.

Tablo 4.

Okuma Hızı Becerisi

\begin{tabular}{lcc}
\hline$N$ & Sinıf Seviyesi & $\%$ \\
\hline 67 & $<2$ & 84.81 \\
9 & 2 & 11.39 \\
3 & 2.5 & 3.80 \\
\hline
\end{tabular}

$N=79$.

Bu araştırmanın ikinci alt amacı olan öğrencilerin okuma hızı becerileri incelenmiştir. Tablo 4'e göre araştırmaya dâhil edilen özgül öğrenme güçlüğü tanılı 3. sınıf öğrencilerinin \%100'ünün ( $n=$ 79) okuma hızı becerilerinin sınıf seviyesinin altında olduğu bulunmuştur. Öğrencilerin \%84.81'inin ( $n$ = 67) okuma hızı becerileri 2. sınıf seviyesinin altında, \%11.39'unun $(n=9) 2$. sınıf seviyesinde ve \%3.80'inin ( $n=3$ ) ise 2.5 sınıf seviyesinde performans göstermiştir.

Tablo 5.

Okuma Hızı Becerisi

\begin{tabular}{lcc}
\hline$N$ & Yaş Seviyesi & $\%$ \\
\hline 69 & $<7$ & 87.34 \\
6 & 7 & 7.60 \\
4 & 7.6 & 5.06 \\
\hline
\end{tabular}

$N=79$.

Tablo 5'e göre araştırmaya dâhil edilen özgül öğrenme güçlüğü tanılı 3. sınıf öğrencilerinin \%100'ünün ( $n=79$ ) okuma hızı becerilerinin kronolojik yaşlarının altında olduğu bulunmuştur. Öğrencilerin \%87.34'ünün $(n=69)$ okuma hızı becerilerinde 7 yaş seviyesinin altında, \%7.60'ının $(n=$ 6) 7 yaş seviyesinde ve $\% 5.06$ ' $\operatorname{s} ı n$ ın $(n=4)$ ise 7.6 yaş seviyesinde performans göstermiştir. 
Tablo 6.

Okuduğunu Anlama Becerisi

\begin{tabular}{ccc}
\hline$N$ & Sinıf Seviyesi & $\%$ \\
\hline 71 & $<2$ & 89.87 \\
8 & 2 & 10.13 \\
\hline
\end{tabular}

$N=79$.

Bu araştırmanın üçüncü alt amacı olan okuduğunu anlama becerileri incelenmiştir. Tablo 6'ya göre araştırmaya dâhil edilen özgül öğrenme güçlügü tanılı 3. sınıf öğrencilerinin \%100'ünün $(n=79)$ okuduğunu anlama becerilerinin sınıf seviyesinin altında olduğu bulunmuştur. Öğrencilerin $\% 89,87$ 'sinin ( $n=71$ ) okuduğunu anlama becerileri 2 . sınıf seviyesinin altında, \%10.13'ünün $(n=8) 2$. sınıf seviyesinde performans göstermiştir.

Tablo 7.

Okuduğunu Anlama Becerisi

\begin{tabular}{lcc}
\hline$N$ & Yaş Seviyesi & $\%$ \\
\hline 77 & $<7$ & 97.46 \\
1 & 7 & 1.27 \\
1 & 7.6 & 1.27
\end{tabular}

$N=79$.

Tablo 7'ye göre araştırmaya dâhil edilen özgül öğrenme güçlüğü tanılı 3. sınıf öğrencilerinin \%100'ünün ( $n=79$ ) okuduğunu anlama becerisinde kronolojik yaşlarının altında olduğu bulunmuştur. Öğrencilerin \%97.46'sının ( $n=77)$ okuduğunu anlama becerisinde 7 yaş seviyesinin altında performans göstermiştir. Sadece bir öğrencinin (\%1.27) 7 yaş seviyesinde ve bir öğrencinin (\%1.27) 7.6 yaş seviyesinde okuduğunu anlama becerisine sahip olduğu tespit edilmiştir.

\section{Tartışma ve Sonuç}

Bu araştırmada özgül öğrenme güçlüğü olan öğrencilerin doğru okuma, okuduğunu anlama ve okuma hızlarını incelenerek bu öğrencilerin sınıf ve yaş seviyesindeki performansları belirlenmiştir. ilk alt problemin sonuçları öğrencilerin doğru okuma becerileri açısından kronolojik yaş ve sınıf seviyesi altında olduğunu göstermektedir. Önceki araştırmalarda benzer sonuçlar ulaşıımıştır. Sarıpınar ve Erden (2010) ilköğretim 1-5. sınıfa devam eden 909, okuma güçlüğü tanısı almış 55 ve hiçbir tanı almamış 55 öğrencinin okuma becerilerini incelemiştir Öğrencilere metinler okutularak öğrencilerin okuma hızı, okuma hataları ve okuduğunu anlama becerileri değerlendirilmiştir. Araştırma bulguları, okuma güçlüğü olan öğrencilerin doğru okuma becerilerinin akranlarına göre anlamlı derecede düşük seviyede olduğunu göstermektedir. Ayrıca okuma güçlüğü olan öğrencilerin okuma hızı ve okuduğunu anlama becerilerinde de akranlarından düşük seviyelerde olduğu bulgusuna ulaşıımıştır. Bir diğer araştırmada Denton, Fletcher, Anthony ve Francis (2006) okuma yetersizliğine sahip öğrencilerin okuduğunu anlama ve akıcı okuma becerilerini geliştirmek amaçlı 5 birinci sınıf, 11 ikinci sınıf ve 11 üçüncü sınıf öğrencisi ile deneysel bir çalışma yapmıştır. Araştırmada öğrencilere 16 haftalık bir müdahale programı uygulanmış, yapılan müdahale sonucunda 12 öğrencinin akıcı okuma ve okuduğunu anlama becerilerinde gelişme gözlenmiştir. Bu araştırmanın özgül öğrenme güçlügü olan öğrencilerin doğru okuma becerilerinde kronolojik yaş sınıf seviyesi altında olduğu sonucu alanyazını destekler niteliktedir.

ikinci alt problemin sonuçları öğrencilerin okuma hızı becerileri açısından kronolojik yaş ve sınıf seviyesinin altında olduğunda göstermektedir. Benzer bulgular mevcuttur. Örneğin, Orsolini, Fanari, Cerracchio ve Famiglietti (2009) okuma yetersizliğine sahip öğrencilerin fonolojik okumalarını ve kelime okumalarını incelemiştir. Araştırmaya birinci sınıfta öğrenim gören okuma yetersizliği olan 14 öğrenci ve okuma yetersizliği olmayan 70 öğrenci katılmış, özgül öğrenme güçlüğü olan öğrencilerin üçüncü sınıfta dakikada ortalama 43.40 kelime okudukları tespit edilmiştir. Araştırmada 
okuma yetersizliğine sahip olan öğrencilerin okuma hızları okuma yetersizliğine sahip olmayan öğrencilere göre daha düşük olduğu bulunmuştur. Ergül (2012) okuma güçlüğü olan 112 öğrencinin okuma performanslarını değerlendirmiş ve öğrencilerin okuma hızlarının üçüncü sınıf seviyesi altında olduğu sonucuna ulaşmıştır. Ayrıca öğrencilerin okuma hızı becerisinde akranlarından ortalama iki yıl geride olduğunu tespit etmiştir. Bu araştırmada özgül öğrenme güçlüğü tanısı almış öğrencilerin okuma hızlarının kronolojik yaş ve sınıf seviyesinin altında olması alanyazını desteklemektedir.

Üçüncü alt problemin sonuçları öğrencilerin okuduğunu anlama becerisinde de kronolojik yaş ve sınıf seviyesinin altında olduğunu göstermektedir. Betjemann ve Keenan (2008) okuma yetersizliği olan öğrencilerin okuduğunu anlama ve fonolojik farkındalık becerilerini incelemiştir. Araştırma 8-18 yaş aralı̆ı̆ıda olan 280 öğrenci ile yapılmıştır. Araştırmada okuma yetersizliği olan öğrencilerin tamamı okuduğunu anlama becerilerinde düşük seviyede performans sergiledikleri sonucuna ulaşılmıştır. Baydık (2011), okuma yetersizliği olan öğrencilerin üst bilişsel okuma stratejilerini kullanımını ve öğretmenlerin okuduğunu anlama ile ilgili öğretim uygulamalarını incelemiştir. Araştırma üçüncü sınıfta öğrenim gören okuma yetersizliği olan ve olmayan 192 öğrenci ve 39 öğretmen ile yapılmıştır. Araştırmada okuma yetersizliği olan öğrencilerin metinde açık ve kapalı olarak verilmiş bilgiye götüren sorularda ve metnin ana temasını bulmada yaşıtlarından düşük seviyede oldukları bulgusuna ulaşılmıştır. Ayrıca okuma yetersizliğine sahip öğrencilerin metni anlama stratejilerini kullanmadan okudukları ve okuma hızında da yetersiz oldukları tespit edilmiştir. Bu araştırmadan elde edilen sonuçlar, alanyazını destekler niteliktedir.

Özel eğitimde ölçme ve değerlendirme bireyin yapabildikleri ve yapamadıklarını belirleyebilmek, bireye etkili bir eğitim programı hazırlayabilmek, bireyin gelişimini sürekli takip edebilmek, gelecek süreçleri planlayabilmek açısından önemlidir (MEB, 2008). Öğrencileri tanılama özel eğitimde önemli bir aşama olmakla birlikte tanılama sonrası yapılan ölçme ve değerlendirme de özel eğitim sürecinin etkililiğinin değerlendirilmesi açısından önem arz etmektedir. Bu araştırmada özgül öğrenme güçlüğü olan öğrencilerin akademik becerilerinin değerlendirilmesi yapılmış, bu öğrencilerin doğru okuma, okuma hızı ve okuduğunu anlama becerilerinde kronolojik yaş ve sınıf seviyelerinin altında performans gösterdikleri tespit edilmiştir. Araştırma sonuçları, özgül öğrenme güçlüğü olan öğrencilerin etkili müdahaleler ile desteklenmesi gerektiğine işaret etmektedir. Etkili müdahale ve stratejilerin uygulandığı araştırmalarda (Denton vd., 2006; Dündar ve Akyol, 2014) kanıtlandığı gibi özgül öğrenme güçlüğü olan öğrencilere gerekli destek sağlandığında akademik becerilerde gelişme gösterebilmektedir. Dolayısıyla özel eğitim ve rehabilitasyon merkezlerinde eğitim gören öğrencilerin daha yoğun bir eğitime tabi olduklarında daha iyi bir akademik performans sergileyecekleri düşünülmektedir.

Özgül öğrenme güçlüğü olan öğrencilerin doğru okuma, okuduğunu anlama ve okuma hızı becerilerinde yaş ve sınıf seviyelerinin altında performans göstermesi etkili stratejilerin ve kanıta dayalı müdahalelerin gerekliliğini göstermektedir. Uygulamaya yönelik öneri olarak hem sınıf öğretmenlerinin hem de özel eğitim öğretmenlerinin hizmetçi eğitimlerle desteklenmesi ve sınıflarda kanıta dayalı müdahalelerin uygulanması öğrencilerin okuma becerilerini destekleyeceği düşünülmektedir.

Bu araştırmaya sadece üçüncü sınıf öğrencileri dâhil edilmiştir. Farklı sınıflarda öğrenim gören özgül öğrenme güçlüğü olan öğrencilerle veya özgül öğrenme güçlüğü olan bireylerin kendi sınıflarında eğitim gördükleri akranlarının da dâhil edildiği bir çalışmanın gelecek araştırmalara katkı sağlayacağı düşünülmektedir. Bu araştırma betimsel tarama modeli kullanılarak yapılmıştır. Etkili stratejilerin ve kanıta dayalı müdahalelerin yer aldığı deneysel bir araştırma, özgül öğrenme güçlüğü olan öğrencilerin okuma becerilerinin geliştirilmesi ve müdahale programının etkililiğinin değerlendirilmesi açısından alana katkı sağlayacağı düşünülmektedir.

\section{Araştırma ve Yayın Etiği}

$\mathrm{Bu}$ çalışmada "Yükseköğretim Kurumları Bilimsel Araştırma ve Yayın Etiği Yönergesi" kapsamında uyulması belirtilen tüm kurallara uyulmuştur. Yönergenin ikinci bölümü olan "Bilimsel Araştırma ve Yayın Etiğine Aykırı Eylemler" başlığı altında belirtilen eylemlerden hiçbiri gerçekleştirilmemiştir. 


\section{Etik Kurul İzi}

Kurul adı = Biruni Üniversitesi Girişimsel Olmayan Etik Kurulu

Karar tarihi $=07.02 .2020$

Belge sayı numarası $=2020 / 37-18$

\section{Yazarların Katkı Oranı}

Birinci yazar (\%60) araştırmanın literatür taramasından araştırmanın son halini almasına kadar bütün bölümlerine katkı sağlamıştır. İkinci yazar (\%40) ise araştırmanın fikir aşamasından araştırmanın tamamlanmasına kadar fikren ve geri bildirimlerle katkı sağlamıştır.

\section{Çıkar Çatışması}

Bu makale ile ilgili herhangi bir çıkar çatışması bulunmamaktadır.

\section{Kaynaklar}

Akyol, H. (2012). Türkçe öğretim yöntemleri. Ankara: Pegem Akademi. ISBN: 978-605-364-001-1

Akyol, H. (2018). Türkçe ilkokuma yazma öğretimi. Ankara: Pegem Akademi. DOI: $10.14527 / 9789758792917$

Amerikan Psikiyatri Birliği. (2013). Ruhsal bozuklukların tanısal ve sayımsal elkitabı, DSM-V Tanı ölçütleri başvuru el kitabı. (E. Köroğlu Çev.). Ankara: Hekimler Yayın Birliği.

Arlı, M. \& Nazik, H. (2010). Bilimsel Araştırmaya Giriş. Ankara: Pegem Akademi. ISBN: 97895757313908.

Baydık, B. (2011). Okuma güçlüğü olan öğrencilerin üst bilişsel okuma stratejilerini kullanımı ve öğretmenlerinin okuduğunu anlama öğretim uygulamalarının incelenmesi. Eğitim ve Bilim, 36(162), 301-319.

Betjemann, R. S. ve Keenan, J. M. (2008). Phonological and semantic priming in children with reading disability. Child Development, 79(4), 1068-1102. DOI: 10.1111/j.1467-8624.2008.01177.x

Büyüköztürk, Ş., Kılıç Çakmak, E., Akgün, Ö.E., Karadeniz, Ş, \& Demirci F. (2008). Bilimsel Araştırma Yöntemleri. Ankara: Pegem Akademi Yayınları.

Carr, S. C. ve Thompson, B. (1996). The effects of prior knowledge and schema activation strategies on the inferential reading comprehension of children with and without learning disabilities. Learning Disability Quarterly, 19(1), 48-61.

Çakıroğlu, O. (2018). Özgül öğrenme güçlüğüne giriş. M.A. Melekoğlu ve O. Çakıroğlu (Ed.), Özgül öğrenme güçlüğü olan çocuklar (s.39). Ankara: Vize Akademi. ISBN: 978605798208.

Çelik, C. Erden, G., Özmen, S., \& Hesapçıoğlu, S.T. (2018). Okuma becerisi ve özgül öğrenme güçlüğü belirtilerinin dikkat eksikliği ve hiperaktivite bozukluğunda değerlendirilmesi. Klinik Psikoloji Dergisi, 2(2), 65-76.

Denton, C.A., Fletcher, J. M., Anthony, J.L., \& Francis, D. J. (2006). An evaluation of intensive intervention for students with persistent reading difficulties. Journal of Learning Disabilities, 39(5), 447-466. DOI: 10.1177/00222194060390050601

Dündar, H. ve Akyol, H. (2014). Okuma ve anlama problemlerinin tespiti ve giderilmesine ilişkin örnek olay çalışması. Eğitim ve Bilim, 39(171), 361-377.

Ergül, M. (2012). Okumada güçlük yaşayan öğrencilerin okuma performanslarının öğrenme güçlüğü riski açısından değerlendirilmesi. Kuram ve Uygulamada Eğitim Bilimleri Dergisi, 12(3), 20332057. ISSN: 1303-0485 / 2148-7561.

Gay, L. R., Mills, G. E., \& Airasian, P. (2006). Educational research: Competencies for analysis and application. New York: Prentice Hall.

Güldenoğlu, B., Kargın, T., \& Miller. P. (2012). İyi ve zayıf okuyucuların kelime işlemlere ve okuduğunu anlama becerilerinin karşılaştırılmalı olarak incelenmesi. Kuram ve Uygulamada Eğitim Bilimleri (KUYEB), 12(4), 2807-2828. 
Harwell, J. M. ve Jackson, R. W. (2008). The complete learning disabilities handbook: Ready-to-use strategies and activities for teaching students with learning disabilities. San Francisco, CA: Joseey-Bass. ISBN-13: 978-0787997557.

Jenkins, J. R., Furhs, L. S., Van Den Broek, P., Espin, C. \& Deno. S. L. (2003). Accuracy and fluency in list and context reading of skilled and RD groups: Absolute and relative performance levels. Learning Disabilities Research \& Pratice, 18(4), 237-245. DOI: 10.1111/1540-5826.00078

Katzir, T., Kim, Y., Wolf, M., O'Brien, B., Kennedy, B., Lovett, M. ve ark. (2006). Reading fluency: The whole is more than the parts. Annals of Dyslexia, 56(1), 51-82. DOI: 10.1007/s11881-0060003-5

Keskin, H. ve Akyol, H. (2014). Yapılandırılmış okuma yönteminin okuma hızı, doğru okuma ve sesli okuma prozodisi üzerindeki etkisi. Ana Dili Eğitimi Dergisi, 2(4), 104-119. DOI: 10.16916/aded.09329

Kordan, H., ve Akyol H. (2018). Koro, tekrarlı ve yardımlı okuma yöntemlerinin zayıf okuyucuların okuma ve anlama becerileri üzerine etkisi. Eğitim ve Bilim, 43(193), 159-179. DOI: 10.15390/EB.2018.7385.

Kuruyer, H., ve Çakıroğlu A. (2017). Sınıf öğretmenlerinin özel öğrenme güçlüğü olan öğrencilerin eğitsel değerlendirme ve eğitimsel müdahale sürecinde görüş ve uygulamaları. Turkish Studies, 12(28), 539-555. DOI: 10.7827/TurkishStudies.12494

Melekoğlu, M. A., Erden, H. G., \& Çakıroğlu, O. (2019). Development of the oral reading skills and comprehension test- II (SOBAT-II) for assessment of Turkish children with specific learining disabilities: Pilot study results. Journal of Educational Issues, 5(2), 131-149. DOI: 10.5296/jei.v5i2.15379

Melekoğlu, O. (2018). Özgül öğrenme güçlüğüne giriş. M. Melekoğlu ve O. Çakıroğlu (Ed.), Özgül öğrenme güçlüğü olan çocuklar içinde (s.13). Ankara: Vize Akademi. ISBN: 978605798208.

Milli Eğitim Bakanlığı (MEB). (2006). Özel Eğitim Hizmetleri Yönetmenliği. Erişim adresi: http://orgm.meb.gov.tr/alt_sayfalar/mevzuat/Ozel_Egitim_Hizmetleri_Yonetmeligi_son.pdf

Milli Eğitim Bakanlığı (MEB). (2008). Özel eğitim ve rehabilitasyon merkezi dil ve konuşma güçlüğü destek eğitim programı Erişim adresi: http://orgm.meb.gov.tr/meb_iys_dosyalar/2014_03/14093220_dilvekonumagldestekeitimpr ogram.pdf

Orsolini, M., Fanari, R., Cerracchio, S., \& Famiglietti, L. (2009). Phonological and lexical reading in İtalian children with dyslexia. Reading and Writing, 22(8), 933. DOI: 10.1007/s11145-0089134-x

Pierangelo, R. ve Giuliani, G. A. (2006). Learning disabilities: A pratical approach to foundations, assesment, diagnosis and teaching. Boston, MA: Pearson College Division. ISBN-13: 9780205459643.

Rasinski, T. V. (2004). Assessing reading fluency. Honolulu: Pacific Resources for Education and Learning.

Saraç, T. ve Çolak, A. (2012). Kaynaştırma uygulamaları sürecinde ilköğretim sınıf öğretmenlerinin karşılaştıkları sorunlara ilişkin görüş ve önerileri. Mersin Üniversitesi Eğitim Fakültesi Dergisi, 8(1), 13-28.

Sarıpınar, E.G. ve Erden, G. (2010). Okuma güçlügü̈nde akademik beceri ve duygusal-motor işlevleri değerlendirme testlerinin kullanılabilirliği. Türk Psikoloji Dergisi, 25(26), 56-66.

Seçkin Yılmaz, S. Ş. ve Baydık, B. (2017). Okuma performansı düşük olan ve olmayan ilkokul öğrencilerinin okuma akıcılıkları. ilköğretim Online, 16(4), 1652-1674. DOI: 10.17051/ilkonline.2017.342983

Stanovich, K. E. (2009). Matthew effects in reading: Some consequences of individual differences in the acquisition of literacy. Reading Research Quarterly, 189(1-2), 23-55.

The United States Department of Education (2016). 38th annual reportto congress on the implementation of the Individuals with Disabilities Education Act. Erişim adresi: https://files.eric.ed.gov/fulltext/ED572027.pdf 
Varol, H. (2017). Akıcılığı geliştirme programı ile okuma becerilerinin geliştirilmesine yönelik bir eylem araştırması (Yayınlanmamış Yüksek Lisans Tezi). Necmettin Erbakan Üniversitesi Eğitim Bilimleri Enstitüsü, Konya.

Vellutino, F. R., Fletcher, J. M., Snowling, M. J., \& Scarlon, D. M. (2004). Specific reading disability (dyslexia): What have we learned in the past four decades? Journal of Child Psychology and Psychiatry, 45(1), 2-40. DOI: 10.1046/j.0021-9630.2003.00305.x

Vural, M. ve Yıkmış, A. (2008). Kaynaştırma sınıfı öğretmenlerinin öğretimin uyarlanmasına ilişkin yaptıkları çalışmaların belirlenmesi. Abant Izzet Baysal Üniversitesi Eğitim Fakültesi Dergisi, 8(2), 141-159.

\section{Introduction}

\section{Extended Abstract}

Students with specific learning disabilities are generally educated in inclusive settings in Turkey. Teachers who received no training for students with specific learning disabilities may have difficulty in evaluating the students' educational performance and creating individualized educational program (Vural \& Yıkmış, 2008). Research has indicated that general education teachers are not well prepared to evaluate students' academic skills, conduct an educational evaluation, and create programs to address the needs of students with specific learning disabilities (Kuruyer \& Çakıroğlu, 2017; Saraç \& Çolak, 2012).

Students with specific learning disabilities predominantly have problems in reading (Harwell \& Jackson, 2008), especially in three dimensions: reading accuracy, reading comprehension, and reading rate (American Psychological Association, 2013). It is critical to evaluate the reading accuracy, reading comprehension, and reading rate of students with specific learning disabilities while creating intervention plans and monitoring students' progress. The purpose of this study is to determine the performance of students with specific learning disabilities at specific grade and age level by examining their reading accuracy, reading comprehension, and reading rate. In this study following research questions were addressed: (1) do students with specific learning disabilities perform at their grade and age level in reading accuracy? (2) do students with specific learning disabilities perform at their grade and age level in reading rate? and (3) do students with specific learning disabilities perform at their grade and age level in reading comprehension?

\section{Method}

Purposeful sampling procedure was employed in this study. There were 305 third grade students with specific learning disabilities attending to 30 special education rehabilitation centers in Konya province in Turkey. Among those centers, 11 of them agreed to participate in this study. The data were collected from 100 students with specific learning disabilities; however, 21 students were excluded from data analysis due to the lack of skills in word-level reading. Thus, final sample included 79 third grade students with specific learning disabilities, 50 males (68\%) and 29 females (32\%).

Oral Reading Skill and Reading Comprehension Test-II (SOBAT-II) was administered in this study. SOBAT-II was developed by Melekoğlu et al. (2019) to evaluate the reading accuracy, reading comprehension, and reading rate of children between the ages of 7-11. SOBAT-II consists of two parallel forms each of which includes 13 texts. Students were asked to read from the first text and keep reading until 10 or more reading errors in two consecutive text. Students were also asked to answer five open-ended questions after reading each text. Reading errors and students' answers were recorded by the test administrator.

Descriptive analysis was used to obtain information about students' demographic information (gender and age) and students' reading performance. Each student's performance (reading accuracy, reading comprehension and reading rate) was typed into an excel form according to the SOBAT-II Administration and Scoring Manual. Percentages and frequencies of students' performance by grade level and age level were calculated. 


\section{Result and Discussion}

Results of this study showed that students with specific learning disabilities performed below their chronological ages and grade levels in reading accuracy (98.73\%), reading comprehension $(100 \%)$, and reading rate (100\%). Further examination indicated that $94.94 \%$ of students $(n=75)$ performed below the second-grade level, $3.79 \%$ of them $(n=3)$ performed at second-grade level, and $1.27 \%$ of them $(n=1)$ performed at third-grade level in reading accuracy. Similarly, $97.46 \%$ of students $(n=77)$ performed below 7-year-old, $1.27 \%$ of them $(n=1)$ performed at 7-year-old, and $1.27 \%$ of them $(n=1)$ performed at 8.6-year-old in reading accuracy. In respect of reading comprehension, $89.87 \%$ of students $(n=71)$ performed below the second-grade level and $10.13 \%$ of them $(n=8)$ performed at second-grade level. In addition, $97.46 \%$ of students $(n=77)$ performed below 7 -year-old, $1.27 \%$ of them $(n=1)$ performed at 7 -year-old, and $1.27 \%$ of them $(n=1)$ performed at 7.6-year-old. With respect to reading rate, $84.81 \%$ of students ( $n=67$ ) performed below the second-grade level, $11.39 \%$ of them $(n=9)$ performed at second-grade level, and $3.8 \%$ of them $(n=3)$ performed between second grade and third grade. Furthermore, $87.34 \%$ of them $(n=$ 69) performed below 7-year-old, $7.6 \%$ of them $(n=6)$ performed at 7-year-old, and $5.06 \%$ of them ( $n$ $=4$ ) performed at 7.6-year-old in reading rate. Results of this study may also show that reading accuracy, reading comprehension, and reading rate influence each other.

Evaluation in special education is important in terms of determining students' abilities, preparing intervention programs, monitoring students' progress, and planning future needs of students (Ministry of National Education, 2008). Although identification of students with special needs is an important step, assessment and evaluation after diagnosis is also vital to determine the effectiveness of the special education process. In this study, third grade students with specific learning disabilities performed below their grade and age level in reading accuracy, reading comprehension, and reading rate. As is evidenced in the research (Denton et al., 2006; Dündar \& Akyol, 2014), students with specific learning disabilities can improve their academic skills when appropriate supports are provided. Therefore, it can be concluded that students who receive their education in special education and rehabilitation centers would demonstrate better academic performance when they receive more intense education. According to the Matthew Effect (Stanovich, 2009), there is a gap in the literacy skills between students who are likely to be successful and who are likely to fail. This gap becomes wider as students continue their education (Stanovich, 2009). In this study, it was revealed that students with specific learning disabilities could not perform at their grade and age level in reading. Thus, it is critical to provide proper interventions in order to close the gap and prevent academic failure.

This study was conducted with third grade students with specific learning disabilities. One avenue of research is to conduct a study with students with specific learning disabilities at different grade levels and their peers without disabilities. Future research might apply an experimental study involving effective strategies and evidence-based interventions to contribute to the field in terms of improving reading skills of students with specific learning disabilities and evaluating the effectiveness of the intervention program. 